\title{
Both thermochemical and bacterial sulfate reduction involved in the formation of MVT Pb-Zn deposits: A case study of the Chipu Pb-Zn deposit, South China
}

\author{
JIA-Xi ZHOU*, KAI LUO AND TAO SUN \\ School of Earth Sciences, Yunnan University, Kunming \\ 650500, China (*Corresponding author, Email: \\ zhoujiaxi@ynu.edu.cn)
}

Revealing the formation mechanisms of reduced sulfur is critical to understanding the genesis of MVT $\mathrm{Pb}-\mathrm{Zn}$ deposits. A large number of studies have shown that either thermochemical sulfate reduction (TSR) or bacterial sulfate reduction (BSR) play an important role in the formation of MVT Pb-Zn deposits. However, the case of both TSR and BSR involved in the formation of MVT $\mathrm{Pb}-\mathrm{Zn}$ deposits is rare.

Located in the western Yangtze Block, South China, the Upper Yangtze $\mathrm{Pb}-\mathrm{Zn}$ metallogenic province covers an area of $170,000 \mathrm{~km}^{2}$ and contains $>400$ Neoproterozoic-middle Permian carbonate-hosted epigenetic $\mathrm{Pb}-\mathrm{Zn}$ deposits totaling $>26 \mathrm{Mt}$ of $\mathrm{Pb}+\mathrm{Zn}$ metal reserves. Among these $\mathrm{Pb}-\mathrm{Zn}$ deposits, the Chipu $\mathrm{Pb}-\mathrm{Zn}$ deposit is hosted by dolostone of the late Ediacaran Dengying Formation. In the Chipu deposit, metal minerals are mostly composed of sphalerite, galena and pyrite, and gangue minerals comprise mainly calcite, dolomite and quartz accompanied with large amounts of bitumen.

NanoSIMS in-situ $\mathrm{S}$ isotope analysis shows that $\delta^{34} \mathrm{~S}$ values of sulfides (sphalerite and its symbiotic pyrite) range from $-31 \%$ to $+34 \%$, which are significantly different from the previously reported $\delta^{34} \mathrm{~S}$ values $(+3-+22 \%)$. Furthermore, our sulfur isotope data can be divided into two distinct groups: i) $-31 \%$ o to $-17 \%$, and ii) $+12 \%$ o to $+34 \%$. The latter group $\left(\delta^{34} \mathrm{~S}=+12-+34 \%\right)$ is overlap with the previously reported sulfur isotope data $\left(\delta^{34} \mathrm{~S}=+3-+22 \%\right)$, implying that TSR plays an important role in the formation of reduced sulfur. However, the former group $\left(\delta^{34} S=-31\right.$ to $\left.-17 \%\right)$ suggests that in addition to TSR, BSR may also play an important role in the formation of $\mathrm{S}^{2-}$. Further research shows the mixing of two isotopically distinct $\mathrm{S}^{2-}$ that was produced by TSR and BSR caused the formation of the Chipu deposit, which means that the local sulfate reduction occurred during the $\mathrm{Pb}-\mathrm{Zn}$ mineralization. This provides new insights for understanding the origin and ore exploration of MVT $\mathrm{Pb}-\mathrm{Zn}$ deposits worldwide.

This work is supported by National Natural Science Foundation of China (41872095, U1812402, 41430315). 